\title{
The Roman Frontier in Britain
}

\author{
by R. G. Collingwood, F.S.A.
}

T $T$ was Augustus who first realized that the Roman Empire could not go on expanding for ever. Horace could write

\section{Caelo tonantem credidimus Iovem \\ Regnare; praesens Divus habebitur Augustus adiectis Britannis \\ Imperio gravibusque Persis ; 1}

but a very real part of Augustus' claim to grateful veneration lay in the fact that he made up his mind to leave Britons and Parthians alone - to seek in them not new subjects, but peaceful and respectful neighbours. Coercere intra terminos imperium ${ }^{2}$ was the advice he left to his successors; and in principle they never departed from it. Claudius might conquer Britain, Trajan Mesopotamia and Dacia; but these were "rectifications," as we say nowadays, not obliterations, of the imperial frontier.

For the frontier of the Empire, as Augustus left it, was far from perfect. Tiberius, concerned above all to maintain intact the system created by Augustus, played here, as everywhere, a waiting game, and did not meddle with the Augustan frontiers. But his successor Gaius, or "Caligula," may have contemplated a conquest, or at least an invasion, of Britain ; he certainly made a demonstration on the shore of the Channel. ${ }^{3}$ And Claudius, the fourth Emperor, took the decisive step. Britain and Gaul were too close together, too intimately linked by geography, blood and civilization, to permit of an unfortified Channel frontier. Southern Britain was already in part Romanized, and the flag followed trade.

The Claudian conquest was well-organized and proceeded at first smoothly. There is some reason to think that, after the first three campaigns, a temporary frontier-line was drawn across the country

1 Odes iii, 5 .
2 Tacitus, Ann. i, $\mathbf{x}$. 


\section{ANTIQUITY}

diagonally from South Devon through Bath, Cirencester and Leicester to Lincoln; this line is marked by a road, the so-called Fosse, which is difficult to explain on any other hypothesis, and there is a famous passage of Tacitus which seems actually to describe its construction as a frontier-line. 1 If so, we have here the first Roman frontier in Britain. There is nothing surprising in the fact that it consists simply of a road studded with forts. Limes, the Latin for a frontier, means a road long before it means a wall or earthwork. Originally it is anything that "goes across," 2 and is especially used for the path or balk between two strips of ploughed land. As a military term it signifies a strategic road, driven through enemy country as a means of conquering it; we find this meaning plainly set forth in Tacitus (e.g. Ann. i, 50 ; ii, 7), Frontinus (Strat. 1, 3) and elsewhere. And one of the earliest Roman conceptions of a frontier was that it should consist merely of such a military road.

After this began a fresh forward movement, into whose vicissitudes we need not here enquire, for its various stages were not, so far as we know, marked by the creation of definite frontier-lines. We can only conjecture that temporary frontiers were from time to time established and cancelled again; but there is only one to which we can actually point. That is Agricola's line established between the Forth and the Clyde to mark the point reached by him, during his great northward advance, in or about the year 8o. Tacitus (Agricola, xxiii) tells us of its construction, and its relics have been found in a number of different places, where smallish earthen forts associated with Flavian objects have been found underlying the larger and more solid structures built two generations later by Lollius Urbicus. ${ }^{3}$ It seems very clear that this limes was soon abandoned; probably in or about 83 , if not earlier ; for Agricola was pushing on, and of the forts which he built while actually conquering the country he seems to have kept only a select few permanently garrisoned. In this case, Camelon appears to have been chosen for this purpose, ${ }^{4}$ but the limes as such was demolished.

1 Tacitus, Ann. xii, 31: cunctaque cis Trisantonam et Sabrinam fluvios cohibere parat (accepting Bradley's emendation for castris antonam, and assuming Trisantona= Trent). This interpretation of the Fosse was advanced by the writer in the fournal of Roman Studies, xiv (1924), where the whole question is discussed.

${ }^{2}$ Limes, limitis : from limus=transversus (cf. limen threshold: so Festus) and the root-it ' going.' Cf. Fabricius, art. 'Limes' in Pauly-Wissowa's Realencyclopädie.

${ }^{3}$ Haverfield, Agricola and the Antonine Wall, Proc. Soc. Ant. Scot., I9 17-18, 174-81. Macdonald, Roman Wall in Scotland, $382-8$.

${ }^{4}$ Macdonald, op. cit., 385-6. 


\section{THE ROMAN FRONTIER IN BRITAIN}

It is curious that on his recall Agricola seems neither to have established a new frontier nor to have re-established this old one. He had by now penetrated into Strathmore, and established himself at least as far north as Inchtuthill, at the confluence of the Tay and the Isla $^{2}$. On his recall, he had not reached any point at which a new frontier could have been drawn. His left flank was menaced by the Perthshire mountains, and no limes could be satisfactorily drawn either parallel to the hills or at right angles to them. Curiously enough, his recall was practically coincident in time with Domitian's organization of the frontier in Germany; but though frontier-organization was in the air, it seems that no steps were taken to construct a frontier in Britain. It used to be thought that Agricola's conquests in the north were abandoned on his recall. Even were that view correct, we should still be unable to say where the evacuation ended, or to point out any limes for the period between Agricola and Hadrian. But it is now fairly clear that the assumption of an immediate withdrawal is baseless. At Inchtuthill, at Ardoch, at Camelon, a close criticism of the results reached by excavators some time ago, proves that the Flavian occupation lasted long enough to fall into several distinct periods, each marked by a good deal of rebuilding. At these three sites-and one ought perhaps to add a fourth, Newstead - the evidence for a prolonged occupation after Agricola's recall is definite in character and respectable in bulk. ${ }^{2}$ But there is as yet no evidence that any definite frontier was constructed for the next forty years. So far as we know at present, the north of England and the south of Scotland were held during this period by a certain number of forts placed at strategic points-how many, we cannot pretend to guess - and " petering out," rather than brought to a definite edge, in the neighbourhood of Perth.

This implies an unsatisfactory military situation. In Scotland, the Romans held a mere strip, long and narrow, roughly defined by the sinuous line Melrose-Edinburgh-Falkirk-Stirling-Perth. East of this line, everything was perhaps in their hands, but west of it lay the

\footnotetext{
${ }^{1}$ Excavations : Proc. Soc. Ant. Scot. 190 1-2, 182-242, and four. Rom. Stud. ix. $113-122$.

${ }^{2}$ Macdonald, The Agricolan Occupation of North Britain, F.R.S., xix, III-1 38. Home, Roman York, 36-37, seems to express dissent, but makes no attempt to reinterpret the facts in any other way, and bases his case on false assumptions as to the implications of Macdonald's theory. For Newstead, see Richmond in Proc. Soc. Ant. $S c o t$. 1923-4, 309-32r. While this was in the press I heard of a further and apparently conclusive confirmation in the excavations going on at Mumrills.
} 


\section{ANTIQUITY}

wild and almost untouched country of the central and western Lowlands and the southern Highlands, a constant menace to so long and so thin a line. Wales and northern England were completely conquered, but not so completely pacified as to permit a safe removal of all troops ; so that the army of Britain was spread out over a strip of country $35^{\circ}$ miles long, whose northernmost point was 200 miles away from the nearest legionary fortress, by a line of communications half of which was dangerously exposed on the flank. It was unsound strategy, and defensible only on the plea that, to Agricola, it represented a temporary phase in the conquest of Scotland; his unceasing offensive gave the enemy no time to hit back. But when the offensive stopped, the weakness of the situation must have appeared at once. And the rebuildings traced by Sir George Macdonald at the Scottish forts suggest that these were more than once, during this period, successfully assaulted and destroyed. This does not imply the annihilation of their garrisons, which according to Roman practice joined hands every summer with the legions from the three great fortresses-York, Chester, Caerleonand formed one or more field armies ; during distant operations, a local rising might easily overpower the small body left in charge of the fort and destroy its buildings. Yet the possibility of such risings proves the general insecurity of the position.

For many years, however, the Romans clung tenaciously to what they had gained. There is no conclusive evidence at present for the exact length of this period. It is probable that a good deal of reorganization took place about the turn of the century, and the northernmost Scottish forts may have been abandoned then ; but this is wholly uncertain. What is certain is that one whole legion disappears from the Army List between 107 and 122. The Ninth "Spanish" Legion lay at York, and we have an inscription recording its presence there in the twelfth tribunicia potestas of Trajan, A.D. 107..$^{1}$ On the other hand, the exceedingly numerous inscriptions connected with the building of Hadrian's Wall do not mention this legion, and we know that about 122 the Sixth "Victorious " legion came over from Germany to take charge of the York fortress. ${ }^{2}$ This implies that the Ninth had disappeared by that time. We also know that at the beginning of Hadrian's reign (in or about $\mathrm{II}_{7}$, that is) there was trouble in Britain amounting to a

${ }^{1}$ C.I.L., vii, 24I, where the date is given as ro8-9; but see Cagnat, Cours d'Epigraphie latine, p. I94.

${ }^{2}$ For the date see Ritterling in Pauly-Wissowa, xii, 1606. 


\section{THE ROMAN FRONTIER IN BRITAIN}

more or less successful revolt, ${ }^{2}$ and that, at some time in the same reign, the Roman army in Britain suffered very heavy casualties. ${ }^{2}$ Putting these facts together, we may date the annihilation of the Ninth Legion about the beginning of Hadrian's reign. ${ }^{3}$ Now it is easy to see how a whole legion might be destroyed when operating in Scotland ; it would merely be another Variana clades on a smaller scale. But our authorities do not suggest, neither is it reasonable to assume, that the legion was attacked and overwhelmed in its own stronghold. Hence the probability is that this disaster was directly due to the unsatisfactory strategical situation following Agricola's recall, and that it served to demonstrate unmistakably the need for a new military policy.

This new policy was expressed in Hadrian's Wall. But this great barrier did not issue fully-formed from any single brain. It was the result of numerous experiments and adaptations whose history is exceedingly intricate and is very far, as yet, from being completely known. In order to arrive at some idea of what really happened, it is necessary to review, however briefly, the general state of the frontiers in Hadrian's time and the policy which he was, during these years, pursuing.

It was the special task of Hadrian to re-emphasize the Augustan precept 'keep the Empire within its boundaries,' and to give it, for the first time, a solid basis by drawing boundaries within which the Empire could be kept. Elsewhere, as in Britain, he constructed frontierworks ; but when these are envisaged as a whole it is clear that their purpose was not so much the defence of the Empire against an aggressive barbarism as the clear and scientific delimitation of its extent, resulting on the one hand in the renunciation of further conquests and, on the other, in a cheaper and more secure defence where defence was needed. The point can hardly be put better than it was put by Pelham: "he abandoned a policy of conquest in the conviction that the empire had reached its natural limits, and required not expansion but consolidation. In this belief he set himself to give the Empire, what it had only imperfectly possessed before, definite and well-marked frontiers." ${ }_{4}$

1 Spartian, Hadr. v, 2.

2 Fronto, $218 \mathrm{~N}$.

${ }^{3}$ Ritterling, $o p$. cit. I669, argues that certain recorded careers (L. Aemilius Karus, L. Novius Saturninus) suggest a decidedly later date-after 120 , and preferably after 125. I cannot think that this is consistent with the legion's absence from the British mural inscriptions.

4 Pelham, Essays on Roman History, 162. 


\section{ANTIQUITY}

The idea of marking a frontier by means of a continuous ditch was far older than Hadrian; it goes back to the ditch of Scipio in Africa ; but it seems to have been first revived and applied, with modifications, to the needs of the Empire by Hadrian. Spartian tells us that about I20-I22 Hadrian erected massive palisades to separate the barbarians (from the Empire, that is). Of these we have abundant traces on the upper German and Rhaetian frontier. Here, before Hadrian's time, the frontier had been the mere fore-edge of a network of forts, built up by degrees during the Flavian-Trajanic period. But what, exactly, was the significance or purpose of the new palisade? It is quite certainly not a continuous fortification. Mommsen's observations are conclusive." "Neither the one nor the other [neither the Pfahlgraben nor the Teufelsmauer, which superseded Hadrian's palisade] was constructed for the defence, as a whole, of the frontier. Not merely was the hindrance. . . . to an assailant slight in itself, but along the line we meet everywhere with commanding positions, morasses, lying in the rear, a want of outlook towards the country in front, and similar clear indications of the fact that in the tracing of it warlike purposes generally were not contemplated." What Mommsen here says of the later German works is a fortiori true of the earlier ; Hadrian's palisade, considered as a military obstacle, shows all the weaknesses enumerated by him and some others of its own. It can only have served two purposes : to mark unmistakably the point at which Roman territory ended, and to facilitate the patrolling of the line by making it difficult for casual bands of robbers to cross it. For such a palisade, though no obstacle to an army, was a real obstacle to petty thieves and cattlelifters. You cannot lift cattle over a nine-foot fence. And if evidence is required that the Roman government took petty thieves seriously, it is to hand in the shape of inscriptions set up by Commodus announcing that he had fortified the Danube bank precisely in order to frustrate these persons. ${ }^{2}$

Elsewhere Hadrian's policy was similar. We may instance the Dobruja frontier, where a ditch was dug and an earthen rampart thrown up, probably, by Hadrian; and the Numidian frontier, where similar works were constructed about the same time. In all these cases, and in others - there is no need to enumerate them exhaustively here ${ }^{3}-$

${ }^{1}$ Mommsen, Provinces of the Roman Empire, E.T. i, 157.

${ }^{2}$ C.I.L., iii, 3385 (=Dessau 395 ) ripam omnem burgis a solo extructis item praesidis per loca opportuna ad clandestinos latrunculorum transitus oppositis munivit : ibid. 10312-3.

${ }^{3}$ Fabricius, art. Limes, in Pauly-Wissowa, xiii. 


\section{THE ROMAN FRONTIER IN BRITAIN}

Hadrian's principle is clear. He first selected the best line for a frontier, and then marked it by means of a continuous work which in certain cases might serve as an obstacle to latrunculi, but was never intended as a military defensive work.

Now let us return to Britain. We do not know what exactly was the situation with which Hadrian had to deal ; but it probably included a recent and far-reaching collapse of the unstable system left behind by Agricola, a collapse which, while not involving the loss of York, did involve the loss of the Ninth Legion. If, as Spartian suggests, this disaster took place about I 7 , some steps must have been taken to stem the tide of defeat before Hadrian's arrival in Britain in 122. And of these steps we have actual relics. There is a road, locally known as the Stanegate, which runs roughly parallel to Hadrian's Wall and a little way south of it. On this road are Roman forts of four different periods : (i) Agricolan, about A.D. 80 ; (ii) late Domitian or early Trajan, about $100^{1}$; (iii) late Trajan, about II 5 ; (iv) Hadrian, about I20. Period (iv) synchronizes with the building of the Wall; period (ii) is unmistakably earlier than the Wall, but very little earlier. The forts of this period ${ }^{2}$ are only explicable as representing a concentration along the Stanegate line a few years before the building of Hadrian's Wall ; and, proving as they do that the Stanegate became a limes about the beginning of Hadrian's reign, they strengthen the evidence for the view that this was the time at which the Ninth Legion was destroyed and the last remnants, if not the whole, of Agricola's northern conquests lost.

The theory of Hadrian's work which held the field till 1925 was as follows. A ditch, more or less of the ordinary Hadrianic type, was dug, and forts were built along it, on a line slightly advanced from the Stanegate. The forts stood on the far side, the enemy's side, of the ditch, doubtless to facilitate operations against the enemy, a fact eloquent of the non-military character of the ditch, the so-called Vallum. Each fort was connected with the Stanegate by a branch road. That was Hadrian's original frontier: whether planned by himself in 122 or by his legates a little earlier does not matter. At a later date, but very little later, the great stone wall was built, complete

1 The separate existence of this period is not proved. Nether Denton was certainly occupied then, but we do not know that it was then first occupied. Archaeologia, lxiv, 303 .

2 Haltwhistle, Burn, and Throp, are the dated examples. For the establishment of their date, see Cumb, and West. Trans., N.S., xiii, 379-381. 


\section{ANTIQUITY}

with its mile-castles and turrets, ${ }^{1}$ linking up the forts directly. The grounds for believing that the Wall was later than the forts and Vallum were various. For one thing, each fort seemed built as a self-contained work, and the Wall abuts against its curved angle as if it had been an afterthought ; for another, the ditches of the forts seemed to run underneath the Wall, which had collapsed into them at various places ; again, the course followed by the Wall seems here and there to have been determined by the presence of the Vallum as already in possession of the ground; and the road which follows the Wall has been conclusively proved by excavation to be later than the Vallum in date. It was therefore believed ${ }^{2}$ that the Wall was an afterthought, due to the discovery that a frontier marked simply by the Vallum was too difficult to patrol efficiently and protect against bands of raiders.

But this is a highly simplified statement of a theory which, taken in its entirety, presented very serious complications. We knew that at one place there was a Wall too many - a turf wall, interposed between the stone wall and the Vallum; it had been suggested that this was Hadrian's Wall, and the stone one that of Severus - for ancient writers ascribe a Wall to each emperor-and the suggestion had been conclusively disproved. We also knew that certain of the forts had been enlarged or rather completely rebuilt on a larger scale, and this enlargement, which certainly took place at an early date, seemed later than the turf Wall and yet earlier than the stone Wall. When all these and other complications were stated, no one but a specialist could keep the theory in his head for five minutes together, and even the most sympathetic continental critics $^{3}$ were moved to pronounce the thing schlechterdings unverständlich and to deplore the Planlösigkeit which it perforce attributed to the Romans.

It is proverbially darkest before the dawn; but some nights manage to get still darker when they have already reached what one might think to be the point of saturation. Since the above theory was formulated, new evidence has come to light which disproves at least

\footnotetext{
1 For a general description of the works, see Collingwood, Hadrian's Wall, a history of the problem, F.R.S., xi, 37-66, or Guide to the Roman Wall, Reid, Newcastle, $6 \mathrm{~d}$.

2 The whole view is set forth in detail in the article Hadrian's Wall, cit. in the preceding note.

${ }^{3}$ I refer to Professor Fabricius, who took endless trouble to understand the English theories during the preparation of his invaluable Limes article for Pauly-Wissowa's Realencyclopädie.
} 


\section{THE ROMAN FRONTIER IN BRITAIN}

some part of it ; but, so far, the effect has not been simplification of the problem but a new complication.

This new evidence is the discovery, at one fort, ${ }^{1}$ that the fort ditches, while underlying the stone Wall, do not underlie, but stop short of, the foundation of another Wall parallel and quite close to it. This other Wall has been razed to the ground when the stone wall was built, but its foundations were left : and these foundations closely resemble the ordinary stone foundation-course of an earth or turf wall. But they are too narrow to support an earth or turf wall of any considerable size, and they are not identical in plan with the foundations of the one piece of turf wall on the Hadrianic line with which we were already familiar : for that has no stone foundation whatever.

But it now turns out that we had often seen this foundation before. It is a good deal broader than the stone Wall, and it has often been noticed that the stone Wall stands on a foundation that is too broad for it. This broad foundation now turns out to be the foundation of the earlier Wall, which has been in some places demolished so as to build the stone Wall on the same foundation, and in other places allowed to stand until the stone Wall had been built parallel to it. ${ }^{2}$

How do these facts modify the theory? It is too early to say : but some things can already be said. First, it is more certain than ever that the forts were built before the stone Wall ; but it now appears that they were not built - or at least, this one fort was not built ${ }^{3}$-before the earlier, broad-foundation Wall, but contemporaneously with it. The theory of originally isolated forts, in this case at least, falls to the ground. Secondly, if the forts were built simultaneously with the early Wall, then early Wall, forts, and Vallum seem to be all simultaneous, and we are once more face to face with the problem why two lines-Wall and Vallum-should have been constructed at one and the

${ }^{1}$ Hull, The Excavations at Aesica, 1925, in Archaeologia Aeliana, 1926, 197-202.

2 The broad foundation may be admirably seen in e.g. Cumb. $\mathscr{E}^{\circ}$ West. Trans. N.s. xi, fig. 6 facing p. 404 .

3 This fact is of importance. Great Chesters (Aesica) lies well away from the Vallum, which therefore it does not deflect. It is therefore open to anyone to hold that this fort, and conceivably one or two others, were built not simultaneously with the Vallum but at a later stage in the development of the frontier, when the broad-foundation Wall was added. In this case, the theory above described as holding the field to 1925 requires only two modifications : $(a)$ the addition of the early broad-foundation Wall before the stone Wall; $(b)$ the hypothesis that certain forts were added at this stage. Personally, I regard this as the only working hypothesis likely to commend itself to those in possession of the facts as now known. 


\section{ANTIQUITY}

same time. The theory that one was a military barrier and the other a civil or legal line of demarcation, is hardly plausible, for (i) the early wall, regarded as a military barrier, must have been futile; (ii) why should not the same work serve both purposes? Mommsen suggested that the Wall and the Vallum were the northern and southern edge of a strip of ground which was the limes proper; but that is surely a counsel of despair. Had so extraordinary an arrangement been necessary, we should expect to find traces of it on other frontiers. Thirdly, we are now more than ever faced with the problem of dating the stone Wall. If the broad-foundation Wall is Hadrian's, when was it replaced by the stone Wall ? For this we seem entirely without direct evidence. ${ }^{1}$ The milecastles and turrets are certainly Hadrianic; their pottery, their coins, their inscriptions, all prove that beyond a doubt. But do they belong to the broad-foundation Wall or the stone Wall ? I cannot discover that any evidence hitherto recorded settles that point. That they do not belong to the previously-known turf Wall is certain ; but that is not necessarily identical with the broad-foundation Wall. Yet the stone Wall where it runs parallel to that piece of turf Wall is not built on a broad foundation.

These questions are certainly answerable; but they are answerable only by further and very highly skilled digging. And for my own part I have little doubt that part of the difficulty lies in the fact that different working parties constructed different parts of the line and were allowed a very considerable latitude in methods. To take one example

${ }^{1}$ I should like to discuss a piece of circumstantial evidence on this head; though to avoid breaking the thread I relegate it to a footnote. The 'centurial stones' which marked the beginning and end of each section of the Wall built by a century acting as an independent working-party certainly belong to the stone Wall, not to that of the broad foundation. I say this because in character and style they resemble the materials of the stone Wall. Now in Wales, centurial stones are quite common; they seem to belong to a period going down to, perhaps, about the end of Trajan's reign, when forts were being built in stone. The fashion of dividing up a fort-rampart into lengths and assigning each length to a century may thus be called a Trajanic fashion; and the Hadrianic forts of the Wall, which belong to a type evolved in Trajan's reign, are thus not the only Trajanic feature on the Wall-- the centurial stones constitute another. Now the Antonine Wall was, as I point out below, divided not into centurial lengths but into much longer sections, plainly more economical to build. I understand the transference of a centurial division of labour from Trajanic fort-walls to a great stone wall under Hadrian, and I understand how, being there found cumbrous, it should be replaced by a better division of labour under Pius ; but I cannot believe that, after the Antonine Wall, anyone would exhume a Trajanic method of building forts and apply it in sheer wantonness and perversity to the stone Wall. I infer that the stone Wall is Hadrianic. 


\section{THE ROMAN FRONTIER IN BRITAIN}

only : in general, the Wall is built of small hammer-dressed stones with very little visible tooling, each stone being of a size to be carried by one man. But at Rudchester Mr Brewis lately found, at the north side of the Wall, a handsome moulded plinth, ${ }^{1}$ and in the length of Wall lately destroyed in rebuilding the road at Heddon-on-the-Wall the stones of the lowest course are enormous blocks two or three feet long.

If Hadrian's policy was to construct frontier-works intended rather as lines of demarcation than as military obstacles, it may be thought that the stone Wall must belong to a much later period-say, to the age of Severus. ${ }^{2} \quad$ But there are strong reasons against this, quite independent of the question (raised above) whether the milecastles and turrets belong to the broad foundation or the stone Wall. And, paradoxical as it may seem, the stone Wall is very far from being a satisfactory military obstacle. It must have been quite $I_{5}$ feet high to the parapet-walk, and that walk, while broad enough to let sentries pass, cannot have been nearly broad enough to allow troops to march, even in single file, behind men actually engaged in fighting. The parapet-walk was only accessible at the turrets, 500 yards apart : unlike the stone wall of a fort, it was not backed by an earthen bank giving access at every point of its length. Even had the garrison been armed with bows and arrows, which they were not, they could not have defended so narrow and inaccessible a line against determined escalade ; and anyone who thinks of the actual armament of Roman auxiliaries will see that they would have been helpless, when perched fifteen feet above ground, against an enemy capable of using archery-fire against them. Perhaps I may here repeat what I have said elsewhere. " "The rampart-walk cannot have been more than three or four feet broad, and that is a very narrow fighting-front. There would be barely room for a man to pass behind the actual firing line. ... It would be practically impossible to reinforce a threatened point, even in the most favourable conditions ; wholly impossible to move wounded men. And a few corpses, or a couple of Caledonians who had effected an escalade, would block the walk entirely.... Let anyone try to imagine a front-line trench during an attack, with the conditions that the 'trench' is a wall-top

1 Archaeologia Aeliana, 1925, p. 103 and plate xiv.

2 My paper on The British Frontier in the Age of Severus (Y.R.S., xiii), was written before the new evidence at Aesica came to light. But I do not see need to withdraw its conclusions in consequence of the new discoveries.

${ }^{3}$ The Purpose of the Roman Wall, in the Vasculum, Oct. 1921. 


\section{ANTIQUITY}

fifteen feet from the ground, and that access can only be had at points 500 yards apart, the turrets taking the place of communication trenches: and he will recognize the impossibility of fighting on the Wall."

The function of the Wall, then, was to serve as an elevated sentrywalk and an obstacle to raiders-to those latrunculi on whose account, as we have seen, Commodus fortified the banks of the Danube. If Commodus thought them worth a chain of forts, why should not Hadrian, if Hadrian it was, think them worth a wall ?

Why Hadrian's line was deserted in favour of the old Agricolan Clyde-Forth limes, we do not know. The forward move made by Lollius Urbicus in the reign of Pius, about twenty years after the establishment of Hadrian's line, is something of a puzzle. It was once believed that the intention was to form a double frontier, so as to make a defence in depth. Two cases of this, beside the British example, have been quoted, one in Germany and one in Dacia ; but in all three cases the theory is erroneous, for the lines in question were rather successive than simultaneous frontiers. In Britain, there is no doubt at all that garrisons were moved up from the Tyne-Solway line to the Antonine Wall and that the older line was left to a great extent, if not altogether, undefended.

The new frontier was far more simply constructed than the old. Instead of a complicated system of works created by a series of experiments, we find here a simple and economically-planned line, intended from the first to have all the features that it ever possessed, and therefore much better designed than Hadrian's Wall. ${ }^{i}$ The Wall itself is of turf in its western portion, of earth and clay in its eastern ; it is based throughout on a stone foundation, about I4 feet broad and well provided with culverts for drainage. It is supposed to have stood about ro feet high and to have had a parapet-walk some 6 feet broad along the top ; and from time to time it expands into a platform on which no doubt stood the signal-towers that were an essential part of every frontier-system. The mile-castles of Hadrian's Wall have here no counterpart ; but the forts are much closer together and more regularly spaced ; whereas Hadrian's average 5 miles apart and are sometimes separated by as much as 8 miles, those on the Antonine wall come at fairly regular intervals of about 2 miles. They are variously built;

1 The chief work is Macdonald, The Roman Wall in Scotland, which summarizes all knowledge to 191I. Later additions by the same author are published in Proc. Soc. Ant. Scot. 1914-15 and 1924-5, and by Miller, The Roman Fort at Balmuildy, I922. 


\section{THE ROMAN FRONTIER IN BRITAIN}

some have ramparts of stone, some of turf, some of earth ; whereas on Hadrian's line all the forts have stone or rather composite ramparts of stone with an earthen or clay bank behind. Another difference is that the barracks of the forts on Hadrian's Wall are of stone, those on the Antonine Wall of wood.

The most interesting feature of the Antonine Wall, however, consists of the so-called ' distance-slabs ' which mark the sections in which it was built. ${ }^{1}$ There are seventeen of these ; they are good-sized slabs, each bearing a certain amount of decoration-the badges of legions, victories, and so forth-and an inscription recording the erection of a stated length of the Wall by such and such a unit in the reign of Antoninus Pius ; the name of the emperor being omitted from one slab only. The series includes pairs of duplicates, and these were placed one at each end of the length to which they refer; also a set of four referring to a length somehow shared between two working-parties, each of which set up a slab for itself at each end of the length concerned. 'There were six working parties, two drawn from each of the three British legions ; an arrangement in striking contrast with that by which Hadrian's Wall (the stone Wall) was divided into minute fractions each built by a single century. The distance-slabs of the Antonine Wall, under Sir George Macdonald's patient analysis, have yielded a remarkably complete and convincing account of the methods by which the northern barrier was constructed.

Something of the history of Lollius' limes can be made out from the remains found by excavation in its forts. It was certainly con-

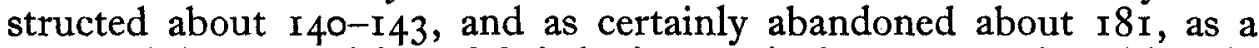
result of the great rising of Caledonians and Maeatae mentioned in Dio (or rather, in Xiphiline's abridgment of Dio) as taking place in that year. ${ }^{2}$ An attempt has lately been made, it is true, to argue that it was held much later. The evidence on which the main Roman occupation of Scotland was dated to c. 140-180 was in the first instance that of coins, as interpreted by Haverfield in $1899 .{ }^{3}$ At that time, accurate dating by the styles of pottery was in its infancy, and the evidence of coins was the only kind that was available for the purpose. Now it has been argued ${ }^{4}$ that coins, under the Roman empire, travelled slowly

1 Macdonald, The Building of the Antonine Wall, in $\mathcal{X} . R . S . \mathrm{xi}, \mathrm{I}-24$.

2 lxxii, 8.

${ }^{3}$ Antonine Wall Report (Glasgow Archaeological Society).

4 Foord, Last Age of Roman Britain. 


\section{ANTIQUITY}

from hand to hand, and took something like $3 \circ$ years to reach so distant a region as Scotland. The cessation of coins at or about 180 , therefore, would prove not that the Antonine Wall was given up then, but that it was held something like 30 years longer, that is, till Caracalla and Geta broke off operations in Caledoria on the death of Severus in 211.1 This theory, however, is based on a mere guess. Its author adduces no single shred of evidence in its favour, except two points neither of which supports it : first, the view of Dr J. G. Milne that coins reached Egypt about five years after they were minted in Rome, ${ }^{2}$ and secondly, Macaulay's ${ }^{3}$ anecdote of the Lancashire quaker, who in the seventeenth century brought undepreciated coins to London some thirty years after depreciation had set in. It is hardly necessary to point out how far these arguments are from proving a thesis which, if true, would be easily provable. In point of fact, it is easily and conclusively disprovable, not only directly by reference to well-known facts but indirectly, because if it were taken seriously it would soon contradict itself ${ }^{4}$.

It is certain, then, that the Antonine Wall was finally evacuated, as such, in or about $18 \mathrm{I}$. But before that date it is archaeologically certain that many of its forts had been destroyed and rebuilt. About I 55, we know from coin evidence that war was going on in Britain, and with this may be connected various records of activity about ${ }_{1} 5^{8}$ by the imperial governor Julius Verus, who restored at that time a number of forts presumably destroyed, to judge from their distribution, by a Brigantian rising. ${ }^{5}$ Pausanias, too, has a reference to a Brigantian war of Antoninus Pius, which may belong to this time. ${ }^{6}$ It seems very possible that this rising resulted in the visible damage to the Antonine Wall. Here and there a second period of destruction and rebuilding has been traced, and these would fall into line with the British war described by Capitolinus ${ }^{7}$ as having been conducted by Calpurnius Agricola. Inscriptions certainly prove that Calpurnius Agricola was active in Northumberland.

\footnotetext{
${ }^{1}$ Foord, op. cit. pp. 32, 50.

2 F.R.S. x, 172.

3 History of England, ch. xxi.

${ }^{4}$ See the reviews by Oman in F.R.S., xvi, Macdonald in History, April r926, and Collingwood in Eng. Hist. Review, April 1926.

5 Haverfield in Proc. Soc. Ant. Scot., 1904, 454 seqq.

6 viii, 43,4 .

7 Marcus Aurel. 8, 7.
} 


\section{THE ROMAN FRONTIER IN BRITAIN}

The final evacuation was certainly due to a disaster. The Wall, says Dio,-he does not say which wall-was broken through, and a Roman general-the word seems to mean the governor himself-fell in battle. Archaeology shows that both Walls were in fact affected, and much else beside. Recent excavations actually suggest that the fortress of York fell ; ${ }^{1}$ and that is quite consistent with Dio's story, for York seems to have been the military centre of Britain and the natural residence for a governor when engaged in military work. Commodus, we are told, was panic-stricken, which again is consistent with the fall of York; and he sent one Ulpius Marcellus to retrieve the disaster. I have argued elsewhere that what Marcellus did was to restore Hadrian's Wall and such of the forts south of it as were necessary for its security. ${ }^{2}$ Nearly a generation later, Severus came over to take the field in person against the Caledonians, and literary tradition ascribed to him the rebuilding or even the original construction of Hadrian's Wall. The evidence of inscriptions makes it wholly impossible to take this literally ; but Severus did no doubt set the frontiersystem on its legs again to some extent, though his actual operations suggest that he wished to imitate Agricola rather than Hadrian and to complete the conquest of Scotland.

After the campaigns of Severus, ending in his death at York in $2 \mathrm{II}$ and his sons' abandonment of the half-finished work, there was a long period of peace, for all we know to the contrary. The forces opposed to Rome were gradually shifting and forming themselves into new shapes, and these new shapes only began to manifest themselves towards the end of the third century. Not that the intervening period was wholly peaceful ; it was not ; but the centre of interest now begins to move. About the years $270-280$ two new factors appear : the Scots of Ireland and the Franks and Saxons of the North Sea. About 270 the Irish, according to their own account, were planting colonies in Pembrokeshire, and there is a good deal of evidence for unrest on the west coast of England about this time. Simultaneously the Saxons began raiding down channel. The result was a gradual inversion of the position on the British frontier. Hitherto the south of Britain had been in constant and close touch with Gaul and, through Gaul, with Rome : her enemies had been on the north, away across the Wall.

\footnotetext{
${ }^{1}$ Or at any rate, that not long after $\mathrm{I} 8 \mathrm{2}$ it was rebuilt. Miller, Roman York, F.R.S. $\mathrm{xv}, 185$.

2 The British Frontier in the Age of Severus, $\mathcal{Y} . R . S .$, xiii.
} 


\section{ANTIQUITY}

Henceforward the Wall was only one of her frontiers, and perhaps not the most important : her most active enemies were engaged in cutting her adrift from the continent, and she had now to defend herself on all sides.

- This changed situation shows itself dramatically in the reign of Carausius, the naval commander who made himself emperor in Britain and, for the first time since A.D. 43, reminded the world that Britain was an island. He was forced into this position by the Saxon seapower, and his severance of Britain from the empire is as it were the anticipation of its final severance, more than a century later. We do not know when the great forts of the Saxon shore, the forts that defended the southern or maritime frontier of Roman Britain, were built : they were probably not all built at once, and it is a reasonable guess that their systematic organization was due to Diocletian and his colleagues at the turn of the third and fourth centuries.

Thus, in the fourth century, we have the Wall to northward; the Yorkshire signal-stations to north-east ${ }^{1}$; the Saxon Shore forts from the Wash to the Isle of Wight, ${ }^{2}$ with outliers of the same type at Cardiff and probably at Holyhead $;^{3}$ and in Wales a series of Romano-British fortified hill-towns, apparently co-operating with the Roman garrison proper against the Irish. ${ }^{4}$ Roman Britain was playing a losing game, into whose vicissitudes this is not the place to inquire. It must suffice to say that the game was played and lost. On any showing, the Wall was given up before the defences of the province finally fell ; according to the present writer's view, the first took place about 383 and the second gradually after a severance of direct relations with the continent that occurred about $4 \mathrm{ro}$; but the matter is much debated at present and the details are little to our present purpose. ${ }^{5}$ Our outline of the various phases of frontier-policy adopted by the Romans in Britain is complete, without any determination of the exact point at which the twilight of fifth century history passes into darkness.

${ }^{1}$ Haverfield, Roman Coast Defences of Britain, F.R.S., ii. Collingwood, The Roman Signal-station on Castle Hill, Scarborough (pamphlet, 2d.)

${ }^{2}$ Mothersole, The Saxon Shore: Haverfield, Litus Saxonicum in Pauly-Wissowa.

3 Wheeler, Segontium (Y Cymmrodor, xxxiii, 97-101).

4 Wheeler, Roman and Native in Wales (Trans. Cymmrodorion Soc. 1920-1).

s See e.g., Bury, The Notitia Dignitatum, F.R.S., x.; Collingwood, The Roman Evacuation of Britain, F.R.S., xii ; Foord, op. cit. and reviews by Macdonald (History Jan. I926), Oman (F.R.S. xiv), and Collingwood (Eng. Hist. Rev. Jan. 1926). 